\title{
Innovation Development to Increase Local Competitive Advantage in Mojokerto Regency
}

\author{
Sri Juni Woro Astuti ${ }^{1}$ \\ Dwi Wahyu Prasetyono
}

\begin{abstract}
Becoming more competitive on the local and national levels can be seen as a strategy that will boost economic growth and, in turn, will improve the welfare of the community. Therefore, local government should make it a priority to draw up a grand plan for local development. The roles of resource-based and local potency in planning, therefore, become critical to improve the performance of local development. With accurate planning, the direction of regional development will be more focused. This paper will examine innovation strategy as an effort to increase local competitiveness, especially in Mojokerto Regency. This study utilizes a qualitative research method, where data is extracted from bureaucrats, community leaders, politicians, and academicians. Interactive data analysis methods, which take place continuously through the processes of data collection, data presentation, and conclusion are used to ensure well-considered results. Research indicates that the success of Mojokerto Regency in building local innovation can be attributed to the development of infrastructure and innovation in public services. This two-pronged approach to spearhead local development allowed Mojokerto Regency to increase its economic growth at an impressive rate. The strategies used to encourage the development of innovation at the local level are threefold, beginning with the alignment of regional development strategy to design long, medium, and short term innovation plans. Secondly, innovation is developed based on regional priorities that support economic growth in sectors that will benefit the wider community. Finally, the success of innovation in Mojokerto Regency is dependent on the support and commitment of local political leaders and apparatus resources.
\end{abstract}

\section{Keywords:}

innovation; poverty; local competitiveness.

\section{Introduction}

One important function of government in this global era is exploring ways to improve the ability of their nation to compete both on a national and regional scale. Competitiveness, in this context, is the ability of the government to develop the economic and social capabilities of an area in order to improve people's welfare and face the dynamic demands of competition on a global scale. The success or failure of these efforts is inseparable from development management, from planning through implementation and monitoring. However, limitations in the development management process are still frequently encountered and become the main obstacle in achieving development goals. This is reflected in the region's failure to meet their success indicators from year to year. At the macro level, the performance indicators of regional development are divided into three areas of focus: public welfare, public service, and competitive edge.

\footnotetext{
${ }^{1}$ Social and Political Science Faculty, Wijaya Putra University. Surabaya.

Email: srijuniworo@uwp.ac.id

${ }^{2}$ Social and Political Science Faculty, Wijaya Putra University. Surabaya.

Email: dwiwahyu@uwp.ac.id
} 
In terms of public welfare, regional development performance measures are primarily focused on economic equality, social welfare, and cultural arts and sports. The performance indicators for the public services sector consist of basic infrastructure such as education, health, environment, and the performance of government officers. The success indicators of regional competitiveness are measured by the state of the local economy, which is reflected in local spending per capita, the availability of transportation infrastructure, settlement facilities, and the ease of doing business in the region, which will attract investors.

In terms of community welfare poverty levels are still high, which indicates that performance could be improved. The challenges of eradicating poverty have not changed over time. Ever since the reform era, poverty alleviation and the public welfare agenda have been seen as a conflict of interest to political parties, especially during legislative and presidential election years. However, the poverty rate in Indonesia is still relatively high. According to data from The Central Bureau of Statistics, in March 2017 the number of people living below the poverty line in Indonesia reached 27.77 million. people (10.64 percent), an increase of 6.90 thousand people over September. The share of the population living below the national poverty line is shown in the table 1.

Based on the data above, Indonesia is the $5^{\text {th }}$ poorest among Asian countries, after Myanmar, Lao People's Democratic Republic, the Philippines, and Cambodia. Judging from the income per capita, Indonesia is also still lagging behind other ASEAN countries such as Singapore, Brunei Darussalam, Malaysia, and Thailand. Indonesia is only superior to the Philippines, Vietnam, Lao People's Democratic Republic, Myanmar, and Cambodia. For example, Indonesia has just reached more than one-third of Malaysian GDP.
Table 1.

The Share of Population Living below the National Poverty Line (\%) in ASEAN Countries

\begin{tabular}{clc}
\hline No & \multicolumn{1}{c}{ Country } & $\begin{array}{c}\text { Poverty line } \\
(\mathbf{\%})\end{array}$ \\
\hline 1 & Myanmar & 25.6 \\
2 & Lao People's Democratic Republic & 23.2 \\
3 & Philippines & 21.6 \\
4 & Cambodia & 14.0 \\
5 & Indonesia & 10.9 \\
6 & Thailand & 10.5 \\
7 & Vietnam & 7.0 \\
8 & Malaysia & 0.6 \\
9 & Brunei Darussalam & No Data \\
10 & Singapore & No Data \\
\hline
\end{tabular}

Source: Basic statistic, ASEAN development bank, 2017

Table 2.

Levels of DGP Per Capita in ASEAN 20152016 (Nominal)

\begin{tabular}{clcc}
\hline No & \multicolumn{1}{c}{ Country } & $\mathbf{2 0 1 5}$ & $\mathbf{2 0 1 6}$ \\
\hline 1 & Singapore & 52.888 & 53.053 \\
2 & Brunei Darussalam & 30.993 & 24.713 \\
3 & Malaysia & 9.501 & 9.546 \\
4 & Thailand & 5.742 & 5.662 \\
5 & Indonesia & 3.362 & 3.636 \\
6 & Philippines & 2.863 & 2.991 \\
7 & Vietnam & 2.088 & 2.164 \\
8 & Lao People's Democratic & 1.787 & 1.921 \\
& Republic & & \\
9 & Myanmar & 1.213 & 1.307 \\
10 & Cambodia & 1.144 & 1.228 \\
\hline
\end{tabular}

Source: International Monetary Fund, World Economic Outlook October 2017, http:// www.imf.org/external/pubs/

Performance is also measured from the public service aspect. This includes the development of basic infrastructure, both physical and social-such as education, health, and the environment. It is also measured by the performance of bureaucratic apparatus services. The achievement of performance development is measured by the Human Development Index (HDI), where Indonesia is still lacking. The 2015 HDI report released by the United Nations Development Program (UNDP) shows Indonesia ranked $110^{\text {th }}$ in 


\section{Chart 1.}

Human Development Index 2015

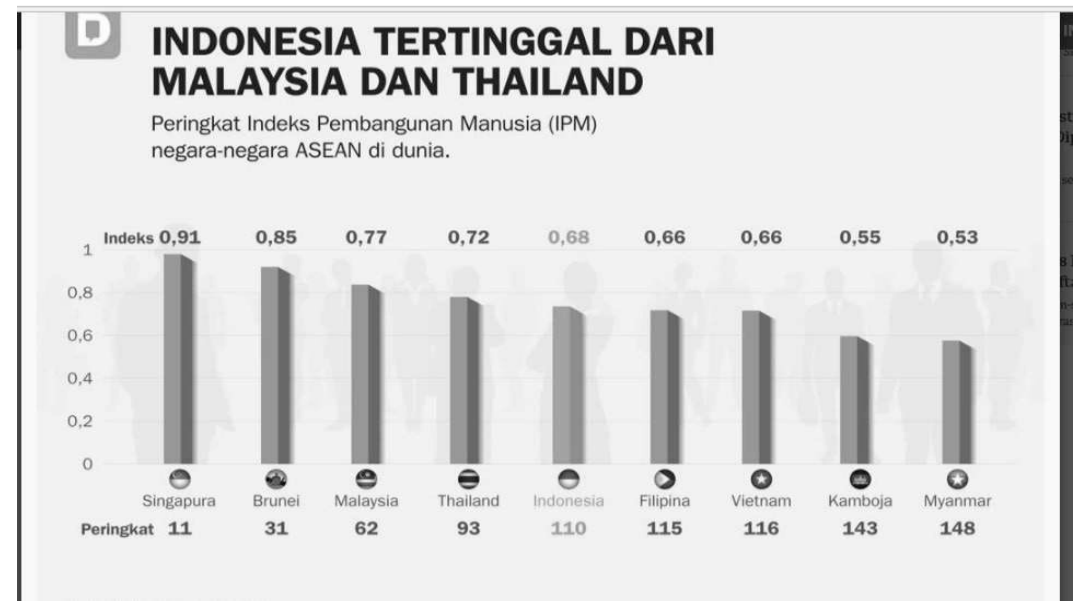

Source: UNDP, 2015

Picture 1.

Global Competitiveness Index

\section{Peringkat Daya Saing Dunia}

\begin{tabular}{|c|c|c|c|c|}
\hline & \multirow{2}{*}{ Negara } & \multicolumn{2}{|c|}{ Peringkat } & \multirow[t]{2}{*}{ Perubahan } \\
\hline & & 2017 & 2016 & \\
\hline 285 & Hong Kong & 1 & 1 & - \\
\hline 4 & Swiss & 2 & 2 & - \\
\hline$\Leftrightarrow$ & Singapura & 3 & 4 & $A 1$ \\
\hline PMODE & Amerika Serikat & 4 & 3 & $\nabla 1$ \\
\hline & Belanda & 5 & 8 & 13 \\
\hline & Irlandia & 6 & 7 & $\therefore 1$ \\
\hline$巨$ & Denmark & 7 & 6 & $\nabla 1$ \\
\hline & Luksemburg & 8 & 11 & $\angle 3$ \\
\hline E를 & Swedia & 9 & 5 & $\nabla 4$ \\
\hline & Uni Emirat Arab & 10 & 15 & $\triangle 5$ \\
\hline & 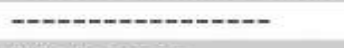 & & & \\
\hline C㱐 & Malaysia & 24 & 19 & $\nabla 5$ \\
\hline = & Thailand & 27 & 28 & $\triangle 1$ \\
\hline 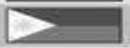 & Filipina & 41 & 42 & $\therefore 1$ \\
\hline$E$ & Indonesia & 42 & 48 & $\Delta 6$ \\
\hline
\end{tabular}

Source: Institute for Management Development (IMD) World Competitiveness Centre, http:// mediaindonesia.com

the world and fifth in ASEAN, far behind Singapore, Brunei, Malaysia, and Thailand. The HDI measures quality of life by considering factors like healthcare, education, politics, human rights, and the environment.

Meanwhile, Indonesia's position on the Global Competitiveness Index could also be improved. This ranking, compiled by the World
Economic Forum, shows Indonesia lagging far behind Singapore, Malaysia, and Thailand. More complete table 4.

Another indicator of a nation's ability to compete on a global scale is the ease of doing business. In this case, Indonesia is still far behind China, Vietnam, the Philippines, and Papua New Guinea. In 2014, the ease of doing 
business in Indonesia was ranked $120^{\text {nd }}$, rising slightly from the year 2013, when Indonesia was ranked $28^{\text {th }}$. The rating is far below other Asian countries. In 2014, Malaysia was ranked $6^{\text {th }}$, Taiwan $16^{\text {th }}$, Thailand $18^{\text {th }}$, Brunei $59^{\text {th }}$, and the Philippines $108^{\text {th }}$. But good developments occurred in 2017 where Indonesia managed to increase its position to $91^{\text {st }}$, but still lags behind compared to Vietnam which is ranked $82^{\text {nd }}$, China $78^{\text {th }}$, Thailand $46^{\text {th }}$, and Malaysia $23^{\text {rd }}$. Therefore, Indonesia should immediately improve itself in all sectors to increase their competitive advantage in the international arena.

Implementing a number of development strategies on both the regional and national levels can be seen as a strategy that will boost economic growth and, in turn, will improve the community welfare. That is, by increasing the competitiveness of the regional economy, the level of social welfare is expected to be better. The implementation of regional autonomy is expected to open up positive opportunities for improvement (http://keuda. kemendagri.go.id/). Local governments should prepare a comprehensive plan to improve the competitiveness of the region.

However, many local governments do not understand the true nature of regional autonomy. Taking advantage of the local development potential is a strategic choice made to fuel economic growth and improve social welfare. This must be functionbased and strategic in order to improve regional development performance. Through appropriate development planning, the necessary focus areas will be more obvious. However, obstacles to the execution of local programs have prevented communities from realizing their full potential.

One of the districts in East Java, the Mojokerto Regency, has successfully improved the quality of life in their community. Mojokerto Regency was awarded an autonomy award for economic development in 2014. Economic growth in Mojokerto stands at $6.92 \%$, a figure that exceeds the level of achievement of the East Java province slightly below Mojokerto Regency, which amounted to $6.55 \%$. Mojokerto per capita income also gradually increased each year, from IDR 22,515,171 in 2012 to US $\$ 25,458,979.23$ in 2013. The HDI ranking of Mojokerto Regency has also increased each year, from $74.42 \%$ in 2012 to $75.26 \%$ in 2013 (Central Bureau of Statistics, Mojokerto Regency, 2015). Mojokerto Regency was honored with Indonesia's Attractiveness Award 2015, where they achieved a total index of 84.43, above Bandung (83.14), Bekasi (82.79), and Sidoarjo (82.20) (http://www. indonesiaattractiveness-award.com/the winner.html). The success that has been achieved was certainly not obtained without commitment and hard work. This paper will examine how innovative development strategies have propelled Mojokerto Regency to the top position in East Java.

\section{Literature Review}

\section{Conceptualizing Poverty, Development, and Welfare}

In general, the idea of innovation in developing countries has not considered poverty as a central issue. Complicating this matter is the lack of understanding about the root causes of systemic, generational poverty. Many people believe that poverty is a result of laziness. Others blame poverty on a lack of support and resources. It's widely believed that insufficient revenue leads to an inability to satisfy basic needs, but also an inability to guide themselves to be fully human (Levine and Rizvi, 2005: 41). The universal indicator is $\$ 2$ per day. People whose income is less than $\$ 2$ per day are said to be living in poverty. Based on this standard, then the low-income people in developed countries could be considered wealthy in comparison. Science has put a double standard in the measurement of poverty among developed and developing 
countries (Chrossudovsky, 2003: 30). Similarly, if this scale is used to measure the standard of subsistence per family, it becomes very problematic. To standardize the measurement of poverty will open up debate on how to define poverty itself.

Poverty can be seen as a byproduct of an inability by a person or agency to perform work in order to survive, though this does not have to ignore their basic needs (Levine and Rizvi, 2005: 76). Poverty can also be the outcome of inefficient use of common resources. This may result from a weak policy environment, inadequate infrastructure, limited access to technology, poor credit, etc. (Olatomide, 2012; 25-36). Therefore, the goal of sustainable development is to meet the needs and improve the welfare of the community, especially the poor who have limited access to resources without intervention.

Development is a process intended to transform an initial condition into a better condition. The concepts of poverty and development in underdeveloped countries are two things that are difficult to reconcile. Poverty lives in the shadows of the development itself. Development is expected to maximize community or social welfare, but the actual effect is often just the opposite. As stated in the goals of sustainable development (SDGs) that is a continuation of the Millennium Development Goals (MDGs), one of its 17 goals is to eradicate poverty in all forms, all over the world. This means that development must be aimed at improving the welfare of society by upholding the principles of justice and equality. This would require good living conditions, the fulfillment of material and spiritual (not necessarily religious) needs, an ordered society, appropriate conflict management, security, justice before the law, and reduced social and economic disparities. Midgley (2005: 21), conceptualized three categories in the attainment of well-being. First, the extent of social problems that can be set. Second, the extent to which the needs can be met. Third, the extent to which the opportunity to improve the standard of living can be obtained. All this can be created, whether within the family, the community, or society at large.

It is crucial to understand the factors that cause welfare disparities, including: (1) household or community socio-economic status, (2) the structure of economic activity sectors, (3) potential of the region (natural resources, environment and infrastructure), and (4) the institutional conditions that form a network of production and marketing on the local, regional, and global levels (Taslim, 2004 in Sururi 2015).

\section{Conceptualizing Integrated Development Planning, System Innovation, and Local Competitiveness}

In this era of regional autonomy, each region has full authority to carry out its mission of development in accordance with the potential and the real needs of the region. Public welfare is one indicator of the success of development in the region. Moreover, entering the era of global competition, the challenges of both national and local governments become increasingly dire. The government must build up public while creating innovations to raise the region's competitive value, both nationally and internationally. For this reason, local and regional development planning needs to be integrated as well as holistic. Integrated Development Plan (IDP) is a process where the planning efforts of various sectors of government and other agencies are coordinated at the local level (Mashamaite and Andani, 2014). It should be seen as tool of redistribution of service provisions to eliminate poverty and hunger. IDP is a critically important management tool that can promote transformation, growth, and development at the local government level (Geyer, 2006 in Mavhungu Elias Musitha, 2016).

Therefore, any integrated development plan should consider the existence of potential 
available resources, as well as challenges in utilizing those resources. Integrated regional development, in this case, is defined as "a political concept of development for regional development by enabling self-assistance. Public budgets are oriented on the target and stimulate economic growth (Dams, 1985). The purpose of this integrated approach to regional development is to include local residents in the global social system. This creates the conditions that allow them to improve their economic and social position. Economic conditions generally receive the most attention, but the real economic issues - such as high unemployment and low income in the community - are linked to broader physical and social problems.

Studies conducted both domestically and abroad show that the process of economic development planning still faces many problems. Emmanuel O. Ojo (2012), identified several, as follows: 1) the plan is too ambitious with little consideration of actual available resources; 2) the lack of an accurate and up-to-date database; 3) a system in which political power is used to push through projects that are not relevant to the reality of public interest. He recommended that development planning should comply with social justice principles and operate under a strict budget. Flexibility in budgeting needs to be eliminated because of the potential for corruption. The research of Astuti, et al (2014) indicated some general constraints, among other things: 1) the mismanagement of data and information; 2) the lack of cooperation between the planning, budgeting, and political processes in translating documents into budgetary planning;3) the lack of community involvement.

Due to these obstacles, some local governments lack the ability to formulate long-term growth plans that are in line with development priorities and strategic issues. The strategic issues facing the region must be addressed by innovative policies. This innovation can be developed in all aspects of society, ranging from public service to public policy to technological advances that are directly aligned with the economic interests of society.

To encourage innovation at the local level, it is necessary to develop a comprehensive development strategy that works within the framework of the system. This is essential to produce, diffuse, and use new knowledge in a way that brings economic benefits to the state (Lundvall, 1992). So, the innovation system is a national system that includes elements and relationships housed or rooted within the state. In another section, Lundvall also said that the innovation system must be a system in which learning, compiling, and extracting data are the central activities. This involves interaction between people or communities and reproduction of knowledge individually or collectively through recall (https://id.wikipedia. org/wiki/Sistem_inovasi). According to Edquist (2001), the innovation system must consider economic, social, political, organizational, and other factors that influence the development, diffusion, and use of innovation. So, as according to Taufik $(2005$,$) the innovation$ system is essentially the union of a host of actors, institutions, relationships, networks, interactions, and productive processes that influence the direction of development and speed of innovation (Ignatius, 2011).

All agree that innovation must happen on a systemic level. Innovation in the context of the product and services industry plays an important role in improving the regional or local competitive advantage in the world economy. However, the development of innovation needs to be designed so that it can be adopted and implemented in a sustainable manner, which, in turn, can contribute substantially to improve the welfare of society.

\section{Methods}

The method used in this study is a qualitative research method, where data is extracted from informants, including 
bureaucrats, community leaders, politicians, and academicians who have relevant insight about policy innovation as it is applied in the government of Mojokerto Regency. In addition to using primary data sources, this study also uses secondary data sources in the form of documents and records related to innovation development in Mojokerto Regency. The study uses interactive date analysis methods throughout, from data collection to data presentation and conclusion or verification.

\section{Result and Discussion}

\section{Finding: Regional Innovation Strategy of Mojokerto Regency}

As explained earlier, the achievements of Mojokerto Regency have many and they have been recognized with two awards. First, as the best district in the corridor MP3EI (Master Plan for the Acceleration and Expansion of Indonesian Economic Development). For this category, Mojokerto Regency has the highest index of 83.4, which exceeds that achieved by the cities of Bandung (83.14), Bekasi (82.79), and Sidoarjo (82.20). Mojokerto Regency also beat the best district of each region from Bali and Nusa Tenggara (Badung 83.4), Borneo (Kutai Kertanegara 75.91), Papua and Maluku (Mimika 61.65), Sulawesi (Minahasa 68.83), and Sumatra (Deli Serdang 81.20). Furthermore, Mojokerto Regency earned the distinction of being named best district in Indonesia with the highest total index of 84.43 in relation to investment interest, the availability of infrastructure, regional growth in tourism, and public service satisfaction. In this metric, Mojokerto achieve the highest index compared to other regencies in Indonesia, such as Sidoarjo, Banyuwangi, Malang, Gresik, Jember, and Tuban (http: //www.indonesiaattractivenessaward. com / the_winner.html).

\section{Infrastructure Development Innovation in Mojokerto Regency}

Mojokerto Regency is located in
Gerbangkertosusilo region, with total area of $969.360 \mathrm{~km} 2$ and total population of about 1.1 million people. The region is experiencing fairly rapid growth in the era of Mustafa Kamal Pasa Regent. Strategy and development policy has been balanced with commitment and implementation in accordance with the priorities of regional development. This has succeeded in increasing the economic growth of the region in 2011 and 2012. Economic growth in Mojokerto increased from $7.03 \%$ in 2011 to $7.25 \%$ in 2012 . The revenue target has increased from IDR 219 million in 2013 to 300 million in 2014. Although growth rates have declined since 2013, the average economic growth in Mojokerto Regency is still higher than the average economic growth of East Java Province, at $6.48 \%$ versus $5.79 \%$ during $2012-2015$.

These numbers can be attributed to the region's commitment to consistency in the development of the budget allocation policy. In accordance with the priorities and results of development planning (musrenbang), Mojokerto district seeks to allocate $70 \%$ of the budget to infrastructure development. Mojokerto District Government realized that infrastructure development plays an important role in driving economic growth and development. The existence of adequate transportation infrastructure is essential. The previous lack of road infrastructure development led to a slowdown in the rate of economic investment in the region. Therefore, to develop local innovation, infrastructure must be built first. These development priorities are in line with the long-term plan of the region as well as medium-term plans to support the development of new industrial centers and improve health services. As Mustafa Kemal Pasa Regent stated:

\footnotetext{
“...It is in accordance with the strategic issues of development in Mojokerto Regency, which include increased access to quality of health services, development and maintenance
} 
of infrastructure, revitalization of agriculture and agro-industry enhancement, improvement of the tourism industry, as well as economic development..." (in-depth interview, March 2016).

Further, Head of Planning Agency Mojokerto Regency explained that:

“...From the implementation of Musrenbang at district level that has held since last February, total proposals from the entire district was $\operatorname{Rp} 748.184$ billion totally for 3,604 activities. The proposal is mostly used in the field of physical infrastructure that were 2,309 activities with a total budget of Rp 563 billion, further in socio-cultural aspect as many as 554 activities with a budget totaling Rp 72 billion, and the last is economics aspect as much as 741 activities while the budget plan totaling Rp 95 billion."

(in-depth interview on March 2016).

The proposal submitted through musrenbang forums is consistent with the program development priorities set out in the Medium-Term Development Plan (RPJMD), 2011-2015, Mojokerto district:

The commitment to build infrastructure has yielded proud results. This is evidenced by Mojokerto's title as the first winner for District Category in 2014, in the Performance Appraisal competition of the Road Utilization Rules of East Java Province level. Of their achievement, Commission III Trenggalek Legislative (East Java) even lauded Mojokerto as a role model for the implementation of development in other regions, particularly in the sector of road improvement. A widening project that began in 2015 has reached $670 \mathrm{~km}$ and is slowly

Table 3.

Priority Programs and Annual Performance Targets, 2011-2015

\begin{tabular}{|c|c|c|c|c|c|c|c|}
\hline \multirow{2}{*}{ No } & \multirow{2}{*}{ Priority Programs } & \multicolumn{5}{|c|}{ Target of performance achievements } & \multirow[t]{2}{*}{$\begin{array}{l}\text { Final } \\
\text { Target }\end{array}$} \\
\hline & & 2011 & 2012 & 2013 & 2014 & 2015 & \\
\hline 1 & $\begin{array}{l}\text { Education facilities \& infrastructure (elementary \& } \\
\text { Junior high schools) }\end{array}$ & $35 \%$ & $42 \%$ & $48 \%$ & $60 \%$ & $60 \%$ & $60 \%$ \\
\hline 2 & $\begin{array}{l}\text { Education facilities \& infrastructure (Senior high } \\
\text { schools) }\end{array}$ & $71 \%$ & $79 \%$ & $86 \%$ & $93 \%$ & $93 \%$ & $93 \%$ \\
\hline 3 & Technical implementation units of education & $60 \%$ & $65 \%$ & $70 \%$ & $80 \%$ & $80 \%$ & $80 \%$ \\
\hline 4 & Number of health centers that have inpatient facilities & 15 & 16 & 16 & 17 & 17 & 17 \\
\hline 5 & Health center service quality improvement & $100 \%$ & $100 \%$ & $100 \%$ & $100 \%$ & $100 \%$ & $100 \%$ \\
\hline 6 & Hospitals service quality improvement & $50 \%$ & $50 \%$ & $50 \%$ & $50 \%$ & $100 \%$ & $100 \%$ \\
\hline 6 & Performance culture facilities improvement & 2 & 2 & 2 & 2 & 2 & 10 \\
\hline 7 & Asphalt construction roads & $95 \%$ & $96 \%$ & $97 \%$ & $98 \%$ & $99 \%$ & $99 \%$ \\
\hline 8 & Roads in good condition & $73 \%$ & $74 \%$ & $75 \%$ & $77 \%$ & $77 \%$ & $77 \%$ \\
\hline 9 & Rehabilitated irrigation networks & 20 & 20 & 20 & 20 & 20 & 100 \\
\hline 10 & Cumulative number of reservoirs, ponds & 7 & 10 & 10 & 12 & 15 & 54 \\
\hline 11 & Rivers normalization & 2 & 4 & 6 & 7 & 8 & 27 \\
\hline 12 & $\begin{array}{l}\text { Number of villages served by the drinking water } \\
\text { company }\end{array}$ & 74 & 77 & 77 & 80 & 80 & 80 \\
\hline 13 & Number of communal sanitation infrastructure & $\begin{array}{c}7 \\
\text { lokasi }\end{array}$ & $\begin{array}{c}10 \\
\text { lokasi }\end{array}$ & $\begin{array}{c}13 \\
\text { lokasi }\end{array}$ & $\begin{array}{c}16 \\
\text { lokasi }\end{array}$ & $\begin{array}{c}19 \\
\text { lokasi }\end{array}$ & 19 lokasi \\
\hline 14 & Addition of Public Street Lighting services & & 50 titik & 50 titik & 100 titik & 100 titik & 100 titik \\
\hline 15 & $\begin{array}{l}\text { Asphalt/paving/macadam environment Road } \\
\text { construction }\end{array}$ & $72,5 \%$ & $73 \%$ & $73,5 \%$ & $74 \%$ & $74,5 \%$ & $74,5 \%$ \\
\hline 16 & Settlement center with good environment road & $60 \%$ & $70 \%$ & $80 \%$ & $90 \%$ & $100 \%$ & $100 \%$ \\
\hline 17 & Road Transport Traffic Supporting infrastructure & $25 \%$ & $35 \%$ & $50 \%$ & $60 \%$ & $75 \%$ & $75 \%$ \\
\hline 18 & Farm infrastructure improvement & 50 & 50 & 50 & 50 & 50 & 250 lokasi \\
\hline
\end{tabular}

Source: Regional Medium-Term Development Plan, Mojokerto District 
approaching the target of $1100 \mathrm{~km}$. To realize the potential of its programs, especially in the development of industrial zones, Mojokerto district continues to do everything possible to attract investors. This can be seen from the efforts to develop industrial estates, such as Ndawar, Jetis, and Kemlagi (regions in Mojokerto Regency), which will follow in the footsteps of the existing industrial region, called Ngoro (an industrial area in the district of Pasuruan). Ngoro has attracted many investors regionally, nationally, and even internationally. This will fuel the creation of jobs and increase local revenue.

\section{Public Services Innovation}

The reputation of public service delivery as rigid and cumbersome needs to be changed by adapting the pattern of citizen charters to put service users at the center of attention. For example, the Department of Population and Civil Registration Mojokerto Regency offers free care programs for families, ID cards, deeds, and non-Muslim marriage certificates, all of which can be processed in one day.

This service can be done on the spot, or through a mobile service, providing that all the files have been completed. The 2015 establishment of the Integrated Licensing and Investment Agency even gives a discount of $50 \%$ for people who filed a tax penalty exemption on a building or occupancy permit (http://bapemas.mojokertokab.go.id). Filing a rebate is very easy. Residents must fill out the form (including the approval of neighbors and letters of authenticity), then provide a certificate or proof of land ownership, a photocopy of applicant's ID card, building plans, and power of attorney, if represented. In addition to issuing building permits, the Integrated Licensing and Investment Agency also serves the Registration of Investment, Land Use Area permit. For Industry and Commerce, subservices provided include: Disturbance Permit or HO, Trade Permit, Company Registration, Industrial
Business License, and Modern Store Permit. Furthermore, in the Field of Business Services, the component subservices consist of permits in the fields of: Health, Media, Employment, Business Registry of Tourism, Licenses of Local Resources, Implementation Billboards, Exploration of Underground Water Drilling, Making Groundwater Use Wells Drill, and Retrieval of Groundwater Through Wells Stake.

The achievement of the Mojokerto Regency government should not be separated from their commitment to innovation strategies implemented over the last few years, especially in the era of Mustafa Kemal Passa Regent and Vice Regent Choirun Nisa (2010-2015). The Mojokerto government's commitment in terms of public service improvement priorities and development activities in 2011-2015 includes: affirming the commitment of the service providers to improving the quality of public services; creating innovative services' addsetting service standards (SPP); an increase in the number of recipients of ISO 9001: 2008; complaint resolution services; information technology development; and the establishment of a public service quality improvement team.

All subservices are integrated into a whole system that is designed to be detailed and transparent for the sake of public convenience and also to attract investors. Another breakthrough undertaken in order to improve public services, is the service partnership between the Social Security Agency and the reception office of the Integrated Licensing and Investment Agency, Mojokerto regency. This counter is ready to provide information and education about health and social security, as well as providing the necessary forms. Steps have been taken to speed up the permit process, such as creating a form that can be downloaded directly from the official website of the Integrated Licensing and Investment Agency, Mojokerto (perijinan. mojokertokab.go.id; read, April 2015).

Commitment to improve the quality of 
public services can also be seen in the existence of the 'service declaration' mandated by the Department of Investment and One Door Integrated Services Mojokerto Regency .The Service Declaration: "We herewith declare that we will be able to provide public services in accordance with established standards and we are able to provide the best service, easy, fast, and transparent to realize the satisfaction of the community in the framework of excellent service" (http://dpmptsp. mojokertokab.go.id/).

The provision of excellent public services needs to be balanced with the ability to communicate well on a systemic level. This communication should not be limited to the process of delivering the message. Rather, any type of nonverbal communication must be considered. The image presented by the government officials as they interact with the public conveys just as much as their words. It is important to establish trust within the community.

Public services innovation in Mojokerto district combines these tangible and intangible factors. An example is the designation of special counseling or complaint rooms that serve as a mediation and troubleshooting space for communication between service workers and the community. This is done solely to fulfill the community needs to obtain better public services from year to year due to an increase in public awareness of their rights as constituents.

\section{Innovation Development Strategy}

The local innovation strategy is a top regional priority and an integral part of the local development strategy. Strategic local innovation is a policy of enhancing the local competitive advantage that focuses on areas of best potential and is open to creative ideas that benefit local progress. Therefore, in drafting innovation strategies, officials must set clear, achievable goals. The Mojokerto Regency development objectives are clearly stated in the local long- and medium-term plans, as follows: "to realize that the people of Mojokerto Regency are independent and growing on the basis of economy, education, and health".

Mojokerto Regency explores their local advantages, including the potential development of an industrial area called Ngoro Industrial Area. Industrial Area Development is intended to encourage the industry sector to become more focused, integrated, and provide more optimal results for the region where the industrial area is located. Key aspects that form the basis of the concept of industrial estate development are efficiency, layout, and environment. An indispensable prerequisite is the availability of adequate road infrastructure so that the efficiency principle will be achieved. Therefore, the development of transportation infrastructure becomes the priority of Mojokerto Regency development. This has public support, as evidenced by the proposed development program that is netted through the development plan meeting described previously.

Thus, the success of local innovation in this regard cannot be separated from the focus of development in the priority area and support from the community. Mojokerto Regency has proven its consistency and commitment to the development priorities that have been formulated in its local long- and mediumterm plans. The commitment is followed by a policy of budget allocation for sustainable infrastructure development.

The next approach taken by Mojokerto Regency is to improve the quality of licensing services, which is closely related to the ease of doing business at the local level. By easing barriers to obtaining licensing, it is expected that investors will want to invest their capital and the expected impact is the improvement of local economic growth. This is in line with the local innovation system objective of creating a conducive investment climate to attract wealth. Abandoning excessive bureaucratic culture and maintaining professionalism will benefit 
Figure 2.

Strategy of Local Innovation Development in Mojokerto Regency

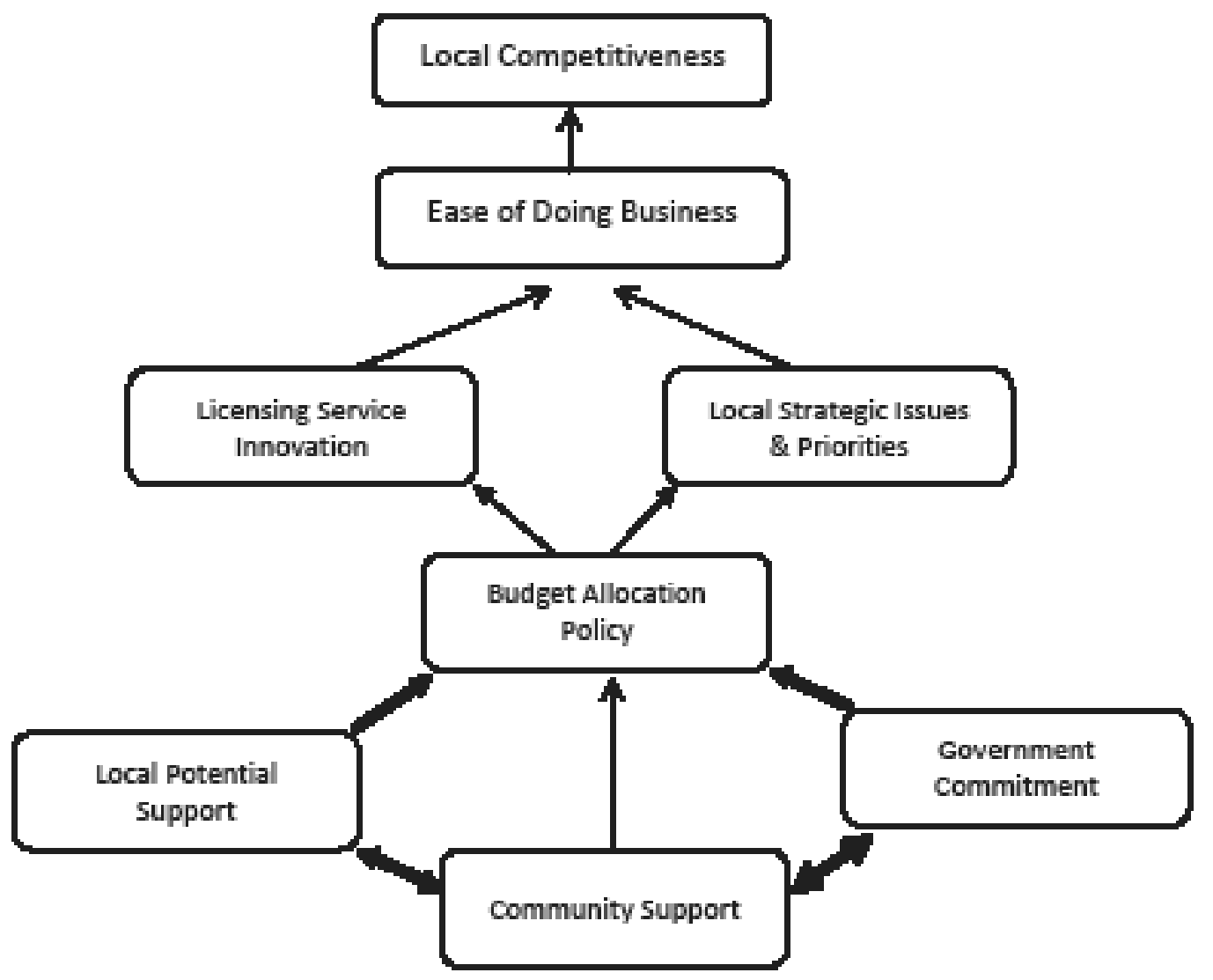

the business climate in the industrial area of Mojokerto Regency. This will create jobs, decrease unemployment, and stimulate local economic growth. The chart below is a model of local innovation development strategy in Mojokerto Regency, which is the result of analysis from this research:

\section{Conclusion}

Mojokerto Regency has experienced a lot of improvement and succeeded in increasing economic growth by $6.92 \%$ by 2014 . This figure even exceeds the level of achievement of East Java province, which was $6.55 \%$. This positions Mojokerto district as a model region that boasts high economic growth (above average) in East Java.

These achievements would not have been possible without the implementation of strategies that have focused on infrastructure development and improvement in the quality of public services from 2011 to 2015. The policy is set out in the Regional Long-Term Development Plan, Medium-Term Plan, and the Local Government Work Plan, which is further manifested in various forms of innovation in infrastructure, product development, and public service.

The success of Mojokerto Regency is in accordance with the basic principles in the development strategy of regional innovation, which include: 1) think strategically and be consistent within the long-term framework; 2) prioritize innovation strategy so that it becomes an integral part of regional development; 3) focus on achievable goals that take advantage of an area's realistic potential to increase regional competitive edge 


\section{References}

Astuti, S., J., W., Dwi, W., P., \& Yudhia, O., P. (2014). The need to revise the policy of regional development planning mechanism: to synchronize the absorption of community aspirations in Indonesia. Paper presented on AAPA 2014 Annual International Conference, Cebu City, Philippines, February 6-8, 2014 .

Badan Pemberdayaan Masyarakat Kabupaten Mojokerto. (n.d.). Retrieved from http:// bapemas.mojokertokab.go.id/index.php?vi

Badan Perencanaan Pembangunan Daerah Kabupaten Mojokerto. (n.d.). Retrieved from http://bappeda.mojokertokab.go.id/

Badan Pusat Statistik Kabupaten Mojokerto. (n.d.). Retrieved from http://mojokertokab. go.id/index.php?vi

Biro Organisasi Sekretariat Daerah Kabupaten Mojokerto. (n.d.). Retrieved from

BPS Kabupaten Mojokerto. (n.d.). Retrieved from http://mojokertokab.go.id/index. php?vi

Chrossudovsky, M. (2003). The globalization of poverty and the new worlds order (2nd ed.). Canada: National Library of Canada Cataloguing in Publication.

Edquist. (2001). The systems of innovation approach and innovation policy: An account of the state of the art. Retrieved from http:// www.druid.dk/uploads/tx_picturedb/ ds2001-178

Emmanuel, O. (2012). Constraints on budgeting and development plan implementation in Nigeria: An overview. European Journal of Sustainable Development, 1(3), 445-456.

Ignatius, S. (2011). Pengembangan pusat inovasi usaha mikro, kecil dan menengah (PI UMKM) dalam kerangka sistem inovasi daerah (SID). Jurnal Sistem Inovasi, 1(1).

Indonesia's Attractiveness Awards. (n.d.). Retrieved from http://www.indonesiaattractivenessaward.com/the_winner. html

Levine, D. P., \& Rizvi, S. A. (2010). Poverty, work and freedom: political economy and the moral order. Cambridge: Cambridge University Press.

Lundvall, B. (2010). National Innovation Systems: Towards a Theory of Innovation and Interactive Learning. London: Anthem Press.

Mashamaite, K., \& Madzivhandila, A. (2014). Strengthening Community Participation in the Integrated Development Planning Process for Effective Public Service Delivery in the Rural Limpopo Province. Mediterranean Journal of Social Sciences, 5(25). doi: 10.5901/mjss.2014.v5n25p225

Mavhungu, E. M. (2016). Integrated development plan as a redistribution policy in South Africa: prospects and Challenges. European Journal of Research in Social Sciences, 4(6), 12-22.

Midgley, J. (2005). Pembangunan sosial, perspektif pembangunan dalam kesejahteraan sosial. Jakarta: Direktorat Perguruan Tinggi Agama Islam Depag RI.

Ojo, E. (2012). Constraints on budgeting and development plan implementation in Nigeria: an overview. European Journal of Sustainable Development 1(3), 445-456.

Olatomide, W. O. (2012). Concept, measurement and causes of poverty: Nigeria in perspective. American Journal of Economics, 2(1), 25-36. doi: 10.5923/j. economics.20120201.04

Sururi, A. (2015). Pemberdayaan masyarakat melalui program pembangunan infrastruktur perdesaan dalam meningkatkan kesejahteraan masyarakat Kecamatan Wanasalam Kabupaten Lebak. Jurnal Administrasi Negara, 3(2), 1 - 25.

Taufik, T. A. (2005). Pengembangan sistem inovasi daerah: Perspektif kebijakan. Jakarta: P2KT PUDPKM- BPPT.

World Economic Forum. (n.d.). Retrieved from http://www.asiabriefing.com/ news/2013/09/asia-improves-internationalcompetitiveness/ 